\title{
Respon Investor atas Tanggung Jawab Sosial Tata Kelola Perusahaan di Indonesia: Perspektif Resource Based View
}

\author{
Amrie Firmansyah ${ }^{1}$ \\ Politeknik Keuangan Negara STAN, \\ Indonesia \\ Pramuji Handra Jadi ${ }^{3}$ \\ Politeknik Keuangan Negara STAN, \\ Indonesia
}

\author{
Wahyudi Febrian² \\ Politeknik Keuangan Negara STAN, \\ Indonesia \\ Mitsalina Khoirun Husna ${ }^{4}$ \\ Politeknik Keuangan Negara STAN, \\ Indonesia
}

\section{Maritsa Agasta Putri ${ }^{5}$ \\ Politeknik Keuangan Negara STAN, Indonesia}

\begin{abstract}
Surel : amrie@pknstan.ac.id
ABSTRAK

Penelitian ini bertujuan untuk menguji pengaruh pengungkapan tanggung jawab sosial perusahaan dan pengungkapan tata kelola perusahaan terhadap nilai perusahaan di Indonesia. Penelitian ini menggunakan sudut pandang perspektif Resource Based View yang masih jarang digunakan dalam pengujian nilai perusahaan. Penelitian ini menggunakan data dan informasi dari perusahaan manufaktur yang terdaftar di BEI dari tahun 2016 sampai dengan 2019. Setelah dilakukan purposive sampling, sampel final yang dapat digunakan sebesar 260 observasi. Pengujian data menggunakan analisis linier berganda dengan data panel. Hasil pengujian menunjukkan bahwa tanggung jawab sosial perusahaan dan tata kelola perusahaan tidak berpengaruh terhadap nilai perusahaan. Hasil pengujian dalam penelitian ini mengindikasikan bahwa Otoritas Jasa Keuangan selaku pengawas emiten di pasar modal Indonesia, perlu untuk meningkatkan pengaturan tata kelola perusahaan dan tanggung jawab sosial perusahaan.

Kata Kunci: Tata Kelola; Keberlanjutan; Pengungkapan; Nilai Perusahaan.

\section{Investor Response to Corporate Social Responsibility and Corporate Governance Disclosure in Indonesia: Resource Based View Perspective}

\begin{abstract}
This study aims to examine the effect of corporate social responsibility disclosure and corporate governance disclosure on firm value in Indonesia. This study uses a Resource Based View perspective which is still rarely used in testing firm value. This study uses data and information from manufacturing companies listed on the IDX from 2016 to 2019. After purposive sampling, the final sample that can be used is 260 observations. Testing the data using multiple linear analysis with panel data. The test results show that corporate social responsibility and corporate governance have no effect on firm value. The test results in this study indicate that the Financial Services Authority as the supervisor of issuers in the Indonesian capital market, needs to improve corporate governance and corporate social responsibility arrangements.
\end{abstract}

Keywords: Governance; Sustainability; Disclosure; Firm Value.

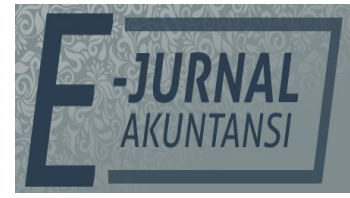

e-ISSN 2302-8556

Vol. 31 No. 8

Denpasar, Agustus 2021

Hal. 1918-1935

DOI:

10.24843/EJA.2021.v31.i08.p04

PENGUTIPAN :

Firmansyah, A., Febrian, W., Jadi, P.H., Husna, M.K., \& Putri, M.A. (2021). Respon Investor atas Tanggung Jawab Sosial Tata Kelola Perusahaan di Indonesia: Perspektif Resource Based View. E-Jurnal Akuntansi, 31(8), 1918-1935

RIWAYAT ARTIKEL: Artikel Masuk: 21 Mei 2021 Artikel Diterima: 24 Agustus 2021

Artikel dapat diakses : https://ojs.unud.ac.id/index.php/Akuntansi/index 


\section{PENDAHULUAN}

Selama pandemi COVID-19, pasar saham telah terpukul cukup keras (Goodell, 2020). Untuk kuartal pertama tahun 2020, pasar modal internasional mengalami penurunan secara signifikan. Sebagian besar perusahaan masih mengalami masamasa sulit untuk bertahan dari dampak pandemi ini. Tingkat keparahan dampak ekonomi dan peningkatan risiko sistemik negara-negara di dunia terlihat jelas (Zhang et al., 2020). Risiko perusahaan di negara yang terkena dampak, terutama risiko keuangan, perlu ditangani dengan tepat untuk memastikan keberlangsungannya dalam jangka panjang. Masalah keberlanjutan perusahaan sangat penting karena sangat terintegrasi dengan ekonomi dunia. Qiu et al. (2021) menyatakan bahwa cara penting untuk membantu perusahaan bertahan dari krisis adalah dengan melindungi dan mempertahankan nilai perusahaan.

Nilai perusahaan memegang peranan penting bagi perusahaan untuk memperoleh modal usaha guna menjalankan kegiatan usahanya. Bagi perusahaan publik, mendapatkan banyak investor yang tertarik untuk berinvestasi di perusahaan mereka sangatlah penting. Salah satu faktor yang menarik investor untuk menanamkan dananya adalah nilai perusahaan. Nilai perusahaan merupakan konsep esensial bagi investor, kreditor, dan pemangku kepentingan untuk pengambilan keputusan investasi untuk mendapatkan capital gain dan mengantisipasi risiko (Riny, 2018). Kondisi ini juga mencerminkan prospek perusahaan yang dapat memberikan kepercayaan kepada investor dan kreditor untuk terus memberikan dukungan dalam aliran masuk modal dan hutang serta membiarkan perusahaan yang mengelolanya dengan harapan memperoleh keuntungan di masa depan dari kegiatan operasionalnya. Pada masa pandemi, semakin penting bagi perusahaan untuk mendapatkan dana yang cukup untuk menjalankan usahanya karena terjadi penurunan daya beli masyarakat (Haryanto, 2020).

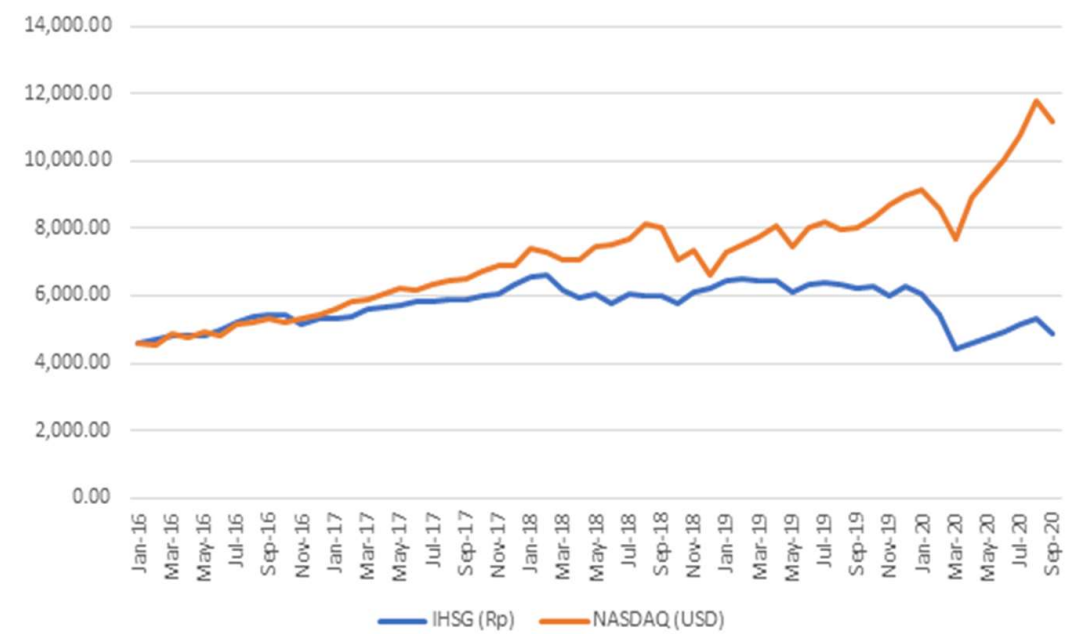

Grafik 1. IDX and NASDAQ Composite 2016 - Q3 2020

Sumber: IDX and NASDAQ Website, 2021 
Berdasarkan Grafik 1, pasar modal telah semakin membaik dan menunjukkan peningkatan rata-rata harga sahamnya. NASDAQ menunjukkan peningkatan yang menjanjikan pada indeks kompositnya dibandingkan dengan IHSG (pasar saham Indonesia). NASDAQ Composite terdiri dari beberapa perusahaan besar, seperti Microsoft, Google, dan perusahaan besar lainnya, yang dinilai memiliki kinerja yang baik oleh pasar. Di sisi lain, IHSG mengindeks seluruh saham yang tercatat di Bursa Efek Indonesia. Perbedaan fluktuasi NASDAQ Composites dan IHSG Composites menunjukkan adanya perbedaan antara bagaimana pasar merespon masing-masing emiten di kedua komposit. Fluktuasi pasar saham dipengaruhi oleh faktor internal dan eksternal perusahaan (Firmansyah \& Purnama, 2020). Angka yang lebih tinggi pada grafik menunjukkan bagaimana pasar merespon dengan baik terhadap perusahaan yang terdaftar, sehingga fenomena ini akan meningkatkan angka pada indeks dan sebaliknya. Respon tersebut berupa kenaikan harga saham perseroan akibat lonjakan permintaan yang dilakukan oleh investor. Harga pasar saham perusahaan sangat penting bagi perusahaan karena mempengaruhi nilai perusahaan (Nuswandari, 2009). Oleh karena itu, konsep nilai perusahaan sangat penting karena mewakili seberapa baik perusahaan dapat membiayai dirinya sendiri melalui perolehan dana dari investor.

Perusahaan dapat memelihara nilai perusahaan dengan mendapat respon positif dari investor. Investor menganggap keberlangsungan perusahaan dapat diwujudkan apabila investor merasa yakin dengan strategi yang dijalankan perusahaan mendukung kepentingan investor. Strategi yang dijalankan oleh perusahaan menjadi faktor penentu perusahaan mendapatkan respon dari investor. Perusahaan yang dapat memenuhi keyakinan investor harus memiliki sumber daya yang baik, terlepas dari kinerja perusahaan. Sumber daya yang dimiliki oleh perusahaan harus dapat dimanfaatkan secara optimal untuk memberikan keyakinan kepada investor yang dampaknya meningkatkan nilai perusahaan. Oleh karena itu, ulasan nilai perusahaan menjadi penting untuk diinvestigasi lebih lanjut.

Beberapa penelitian sebelumnya telah menggunakan faktor-faktor dalam pengujian terhadap nilai perusahaan. Faktor-faktor yang diduga terkait dengan nilai perusahaan tersebut dapat dikelompokkan menjadi beberapa kategori, misalnya pada kebijakan dividen (Bahrun et al., 2020), (Salman et al., 2020), (Handriani \& Robiyanto, 2018), (Raz \& Amir, 2014), (Skinner \& Soltes, 2009), keputusan investasi (Bahrun et al., 2020), (Tyastari et al., 2017), (Handriani \& Irianti, 2015), tata kelola perusahaan (Firmansyah et al., 2020) (Sutrisno, 2020), (Pibri, 2021), derivatif (Firmansyah \& Purnama, 2020) (Irawanti et al., 2018), (Frensidy, 2019), tanggung jawab sosial perusahaan (Gaol et al., 2021), (Fatchan \& Trisnawati, 2016), (Gunawan \& Mayangsari, 2015), (Jo \& Harjoto, 2011) dan income smoothing (Novianti \& Firmansyah, 2020).

Penelitian ini menggunakan aktivitas tanggung jawab sosial dan tata kelola perusahaan (good corporate governance) untuk diuji terhadap nilai perusahaan. Sumber daya perusahaan yang dapat meningkatkan nilai perusahaan akan optimal apabila perusahaan mempertahankan etika bisnis yang dijalankannya dan transparansi dalam pemberian informasi kepada publik. Kedua komponen tersebut erat kaitannya dengan tanggung jawab sosial 
perusahaan dan tata kelola perusahaan yang relevan khususnya di masa pandemi karena pasar lebih memperhatikan dan cenderung lebih berhati-hati dalam menginvetasikan dana mereka.

Tantangan untuk mempertahankan nilai perusahaan selama pandemi meningkat karena investor cenderung menahan sumber daya mereka dibanding menginvestasikannya selama krisis karena ketidakpastian yang ditimbulkan oleh pandemi. Perusahaan dapat menarik investor apabila perusahaan telah mendapatkan kepercayaan investor terlebih dahulu. Kepercayaan yang diperoleh perusahaan-perusahaan tersebut diyakini sebagai hasil dari pengungkapan informasi yang lebih baik dari pada perusahaan-perusahaan yang tercatat di BEI yang kemudian tercermin pada harga sahamnya (Firmansyah \& Purnama, 2020). Informasi yang diungkapkan meliputi informasi yang terkait dengan aspek non keuangan perusahaan, seperti tanggung jawab sosial perusahaan (CSR) dan tata kelola perusahaan. Stakeholder menuntut tanggung jawab sosial dari perusahaan, sehingga perusahaan mengadopsi konsep 3P yang dikembangkan oleh (Elkington, 1998), yaitu People, Planet, dan Profit yang biasa disebut juga dengan Triple Bottom Line. Konsep tersebut menyatakan bahwa kinerja perusahaan dapat diukur dari keuntungannya dan seberapa besar kontribusi perusahaan terhadap kelestarian lingkungan dan kesejahteraan masyarakat. Selain itu, konsep tersebut saat ini dikenal secara global dengan Keberlanjutan (Sejati \& Prastiwi, 2015).

Banyak perusahaan berusaha memenuhi permintaan ini dengan melindungi pemangku kepentingannya, seperti pelanggan, karyawan, dan masyarakat, meskipun ada tekanan keuangan akibat wabah (Mao et al., 2020). Selain aspek sosial yang diharapkan ditindaklanjuti oleh perusahaan, perusahaan juga diharapkan dapat menjaga kelestarian lingkungannya. Alasan klaim ini adalah perusahaan menggunakan banyak sumber daya alam untuk bertahan hidup dan menjalankan kegiatan operasionalnya yang seringkali merusak ekosistem alam. Untuk melanjutkan kegiatan operasionalnya, maka penting bagi perusahaan untuk menjaga kelestarian lingkungan agar bisnisnya dapat berkelanjutan. Untuk memberikan informasi tentang masalah ekonomi, sosial, dan lingkungan, perusahaan di Indonesia membuat laporan keberlanjutan yang mengukur, mengungkapkan, dan mempertanggungjawabkan kinerja organisasi dalam mencapai tujuan pembangunan berkelanjutan kepada pemangku kepentingan internal dan eksternal (Global Reporting Initiative, 2013). Informasi tersebut dapat mencerminkan kinerja organisasi dalam dimensi ekonomi, sosial, dan lingkungan, yang dapat menjadi media bagi perusahaan untuk menginformasikan kinerja non keuangannya kepada para pemangku kepentingan. Kinerja lingkungan perusahaan dapat dilihat dari kegiatan operasional dan dampaknya terhadap lingkungan, seperti pengelolaan limbah, emisi karbon, emisi gas rumah kaca, dan perubahan iklim. Kinerja sosial perusahaan dapat dilihat dari bagaimana perusahaan mengelola hubungan baik dengan karyawan, pemasok, pelanggan, dan masyarakat sekitar operasional bisnisnya. Sementara itu, kinerja ekonomi dinilai berdasarkan nilai ekonomi yang dihasilkan (pendapatan) langsung, nilai ekonomi yang didistribusikan, keberadaan pasar, dampak ekonomi tidak langsung, dan praktik pengadaan. Beberapa penelitian telah dilakukan terkait dengan pengungkapan tanggung jawab sosial perusahaan terhadap nilai perusahaan. Guidry \& Patten (2010) 
menemukan bahwa perusahaan dengan pengungkapan laporan keberlanjutan berkualitas tinggi memiliki reaksi pasar yang lebih disukai daripada pengungkapan berkualitas rendah. Selain itu, Latifah \& Luhur (2017) menyimpulkan bahwa pengungkapan laporan keberlanjutan meningkatkan nilai perusahaan. Gunawan \& Mayangsari (2015) mengemukakan bahwa tanggung jawab sosial perusahaan tidak berpengaruh terhadap nilai perusahaan. Adanya perbedaan pengujian sebelumnya mengakibatkan pengujian pengungkapan tanggung jawab sosial terhadap nilai perusahaan perlu diinvestigasi lebih lanjut.

Di era yang tidak pasti ini, semakin penting bagi investor dan kreditor untuk menilai kesejahteraan perusahaan dengan memeriksa tata kelola perusahaan. Tata kelola perusahaan yang baik merupakan sistem yang mengatur dan mengontrol cara kerja perusahaan, yang diharapkan dapat memberikan dan meningkatkan nilai perusahaan kepada pemegang saham. Kinerja tata kelola perusahaan dapat dilihat dari kepemimpinan perusahaan, pengendalian internal, dan hak pemangku kepentingan. Perusahaan dengan tata kelola perusahaan yang baik kemungkinan besar akan memenuhi kewajibannya kepada semua pemangku kepentingan dan berkontribusi pada pertumbuhan berkelanjutan melalui mekanisme pemantauan yang memadai. Pengungkapan tata kelola berfungsi sebagai alat analisis bagi investor untuk mendeteksi potensi masalah dalam tata kelola perusahaan sedini mungkin sehingga investor dapat mengukur nilai investasi dan risiko bisnis secara efektif. Terkait aspek tata kelola yang baik, Putu et al. (2014) menyatakan bahwa pengungkapan good corporate governance berpengaruh positif terhadap nilai perusahaan. Akan tetapi, Fatchan \& Trisnawati (2016) mengungkapkan bahwa tata kelola perusahaan yang baik tidak mempengaruhi nilai perusahaan. Ketidakkonsistenan penelitian inilah yang menjadi alasan mengapa penelitian ini dilakukan untuk menguji kembali korelasi pengungkapan laporan berkelanjutan dan tata kelola perusahaan yang baik terhadap nilai perusahaan.

Penelitian ini mengkaji dampak pelaporan keberlanjutan dan pengungkapan tata kelola perusahaan terhadap nilai perusahaan. Firmansyah et al. (2021) menguji CSR dan CG terhadap nilai perusahaan dari sudut pandang teori pensinyalan dan menggunakan data perusahaan sektor kimia, plastik, dan pengemasan, sedangkan penelitian ini menggunakan pendekatan resource based view theory dan menggunakan data perusahaan manufaktur. Dalam Firmansyah et al. (2021), penggunaan CSR dibagi per masing-masing komponen sedangkan dalam penelitian ini komponen tersebut disatukan dengan alasan bahwa ketiga komponen dalam konteks etika bisnis perusahaan dapat menjadi satu kesatuan yang tidak dapat dipisahkan. Penggunaan tata kelola perusahaan dalam penelitian sebelumnya diwakili oleh komisaris independen, komite audit, dan kepemilikan institusional untuk menilai tata kelola perusahaan, sedangkan penelitian ini menggunakan implementasi tata kelola sebagaimana Surat Edaran Nomor 32/SEOJK / 04/2015 tentang Pedoman Tata Kelola Perusahaan Terbuka. Ketentuan tersebut sejalan dengan penerapan tata kelola sebagaimana yang diatur oleh OECD seperti yang digunakan oleh Firmansyah \& Triastie (2020) dan Saksessia \& Firmansyah (2020), namun menggunakan ketentuan yang telah berlaku di Indonesia dan didukung oleh Otoritas Jasa Keuangan selaku badan pengawas pasar modal di Indonesia. 
Menurut Barney (1991), dalam Teori Pandangan Berbasis Sumber Daya, sumber daya dapat dikategorikan sebagai modal fisik, modal manusia, dan modal organisasi. Sumber daya memungkinkan perusahaan untuk memahami dan menerapkan strategi serta meningkatkan efisiensi dan efektivitasnya (Wernerfelt, 1984). Tidak semua sumber daya perusahaan memiliki potensi keunggulan kompetitif yang berkelanjutan. Salah satu sumber daya yang dapat mempertahankan keunggulan kompetitif adalah reputasi positif perusahaan di antara pelanggan dan pemasok (Porter, 1980). Klein \& Leffler (1981) menyatakan bahwa reputasi perusahaan yang positif dapat dianggap sebagai hubungan sosial antara perusahaan dan pemangku kepentingan utama. (Hooghiemstra, 2000) menyatakan bahwa pengungkapan tanggung jawab sosial merupakan instrumen komunikasi antara perusahaan dan pemangku kepentingan yang dapat menciptakan, melindungi, atau meningkatkan citra atau reputasi mereka. Pengungkapan tanggung jawab sosial memiliki manfaat bagi komponen internal dan eksternal perusahaan. Manfaat bagi komponen internal perusahaan adalah dapat memotivasi manajemen untuk meningkatkan efektivitas dan efisiensi dalam kegiatan operasionalnya dan niscaya meningkatkan produktivitas. Adapun manfaat bagi komponen eksternal adalah dapat membangun hubungan yang baik dengan pemangku kepentingan serta meningkatkan reputasi perusahaan yang erat kaitannya dengan diperolehnya keunggulan kompetitif. Manfaat bagi komponen internal dan eksternal akan berdampak pada nilai perusahaan. Selain tanggung jawab sosial, tata kelola perusahaan juga dapat menjadi strategi bagi perusahaan karena berkembang pesat di antara pemangku kepentingan. Dengan memenuhi harapan stakeholders, nilai perusahaan akan meningkat.

Menurut pandangan berbasis sumber daya, sumber daya perusahaan yang dapat menghasilkan keunggulan bersaing adalah sumber daya yang dapat memberikan nilai ekonomis bagi perusahaan, dan nilainya harus langka, tidak dapat disubstitusi, dan sulit ditiru oleh pesaing (Barney, 1991). Reputasi adalah salah satu bentuk aset tidak berwujud yang sulit ditiru tetapi sangat berharga karena reputasi dibangun, bukan dibeli, yang menjelaskan nilai strategis yang dimilikinya bagi perusahaan (Branco \& Rodrigues, 2006). Perusahaan melakukan kegiatan CSR dianggap dapat menciptakan keunggulan kompetitif. Pelaksanaan kegiatan CSR perusahaan dapat menguntungkan perusahaan dari komponen internal dan eksternal perusahaan. Misalnya, perusahaan yang berpartisipasi dalam CSR terkait karyawan dapat memperoleh kepercayaan karyawan dan memotivasi mereka untuk bekerja lebih produktif, sehingga menjadi keunggulan kompetitif dari para pesaingnya. Perusahaan yang memiliki tanggung jawab sosial perusahaan yang baik dan juga tata kelola perusahaan dapat meningkatkan hubungan dengan aktor eksternal, sehingga secara tidak langsung perusahaan mendapatkan keunggulan bersaing melalui hubungan baiknya dengan pihakpihak yang terlibat.

Russo \& Fouts (1997) menyatakan bahwa kinerja yang unggul dalam arena lingkungan dan komunikasi yang efektif dapat memberikan keunggulan kompetitif kepada perusahaan, termasuk reputasi positif yang kuat. Aktivitas tanggung jawab sosial yang meliputi lingkungan, sosial dan ekonomi menjadi komunikasi yang efektif sehingga dapat memperkuat dan membedakan posisi perusahaan melalui efek positif dari reputasi yang baik. Reputasi yang baik dapat 
menjadi keunggulan kompetitif bagi perusahaan yang dapat menarik investor untuk menanamkan dana dalam perusahaan karena mereka yakin bahwa perusahaan tersebut akan memberikan laba yang berkelanjutan, nilai pasar yang lebih tinggi, dan biaya yang lebih rendah (Eccles et al., 2007). Qiu et al. (2016) menyatakan bahwa pengungkapan lingkungan yang objektif dan ekstensif seperti itu meningkatkan reputasi perusahaan dan membawa manfaat ekonomi bagi perusahaan, termasuk harga saham yang lebih tinggi. Selain itu, pelaporan pengungkapan sosial, seperti praktik perusahaan dalam hal keragaman, kesetaraan gaji, dan perdagangan yang adil dapat membantu perusahaan menarik dan mempertahankan karyawan yang berkualitas (Cormier et al., 2011), meningkatkan moral karyawan, motivasi, komitmen, loyalitas, dan produktivitas. Membangun niat baik dan kepercayaan dengan pemangku kepentingan utamanya membantu mengurangi biaya transaksi perusahaan (misalnya, menurunkan perputaran karyawan). Melaporkan praktik perusahaan dalam hal keragaman, kesetaraan kompensasi, dan ketentuan perdagangan yang adil dapat mengurangi konflik distribusi (Qiu et al., 2016). Selanjutnya, tanggung jawab ekonomi perusahaan juga fundamental sebagai bagian dari pembangunan berkelanjutan karena dimensi tanggung jawab lain bergantung pada pemenuhan tanggung jawab ekonomi (Branco \& Rodrigues, 2006).

Perusahaan dengan reputasi tanggung jawab sosial yang sangat baik dapat meningkatkan hubungan dengan pihak eksternal seperti pelanggan, investor, bankir, pemasok, dan pesaing. Jika perusahaan memiliki hubungan yang baik dengan pihak eksternal maka perusahaan tersebut akan memiliki nilai tambah. Nilai tambah ini dapat memudahkan perusahaan dalam menjalankan aktivitas operasional dan kemudahan lainnya. Kemudahan yang diperoleh perusahaan mengurangi biaya yang dikeluarkan oleh perusahaan sehingga dapat menghasilkan laba yang lebih tinggi. Jika perusahaan memperoleh laba yang tinggi maka akan menarik minat investor untuk menanamkan modalnya di perusahaan tersebut. Perusahaan dengan laba tinggi akan lebih memiliki kepastian di masa depan untuk lebih percaya diri dengan keputusan investasinya. Oleh karena itu, hipotesis pertama penelitian ini adalah sebagai berikut.

$\mathrm{H}_{1}$ : Pengungkapan tanggung jawab sosial berpengaruh positif terhadap nilai perusahaan.

Menurut resource-based view, pengungkapan tata kelola (misalnya, komposisi dewan) dapat menambah nilai bagi perusahaan. Dewan direksi dapat dilihat sebagai sumber daya perusahaan yang berharga ketika secara aktif terlibat dalam pengambilan keputusan strategis (Madhani, 2017). Pengetahuan dan pengalaman dewan yang mendalam merupakan sumber keunggulan kompetitif yang sulit ditiru oleh pesaing. Berdasarkan RBV, dewan direksi akan dilihat sebagai unik, kompleks secara sosial, dan sumber daya internal, yang dapat membantu perusahaan untuk meningkatkan kinerja (Hart, 1995). Pengungkapan tata kelola juga mempengaruhi operasi mereka. Dengan mengungkapkan tata kelola, mereka akan berupaya melaksanakan tata kelola perusahaan yang baik mengikuti praktik dan standar umum, seperti meningkatkan kualitas tanggung jawab dewan, melaksanakan keterbukaan informasi publik, meningkatkan kualitas komunikasi dengan pemangku kepentingan, serta menegakkan antikorupsi dan kebijakan anti penipuan. Kondisi ini dilakukan untuk 
meningkatkan reputasi perusahaan, membangun kembali kepercayaan masyarakat, meningkatkan kondisi kinerja (Whitelock, 2015) yang dapat menarik para pemangku kepentingan untuk memberikan komitmen dan investasi jangka panjang. Semakin banyak investor yang tertarik untuk menanamkan modalnya di perusahaan maka akan semakin meningkatkan nilai perusahaan. Oleh karena itu, hipotesis penelitian yang kedua adalah sebagai berikut.

$\mathrm{H}_{2}$ : Pengungkapan tata kelola berpengaruh positif terhadap nilai perusahaan.

\section{METODE PENELITIAN}

Penelitian ini merupakan penelitian kuantitatif. Data penelitian bersumber dari laporan keuangan dan laporan tahunan perusahaan yang diperoleh dari www.idnfinancials.com, www.idx.co.id, dan situs resmi perusahaan. Subjek penelitian adalah perusahaan sektor manufaktur dengan tahun observasi dari 2016 sampai dengan tahun 2019. Perusahaan manufaktur dipilih karena merupakan perusahaan dengan sektor terbesar dalam Bursa Efek Indonesia. Adapun pemilihan periode observasi yang dimulai dari tahun 2016 karena sesuai dengan periode penerapan efektif Pedoman Tata Kelola Perusahaan berdasarkan Surat Edaran Otoritas Jasa Keuangan Nomor 32 tahun 2015. Sampel ditentukan dengan menggunakan teknik pemilihan sampel non acak (purposive sampling) dengan kriteria sebagai berikut.

Tabel 1. Sampel Penelitian

\begin{tabular}{lc}
\hline Kriteria & Jumlah Perusahaan \\
\hline Perusahaan yang terdaftar di BEI per Juni 2020 & 634 \\
Perusahaan yang terdaftar di BEI setelah 1 Januari 2015 & -192 \\
$\begin{array}{l}\text { Perusahaan yang terdaftar di BEI sebelum 1 Januari 2015 } \\
\text { Perusahaan yang tidak termasuk dalam sektor non }\end{array}$ & 442 \\
manufaktur/industri & -303 \\
Perusahaan dengan memiliki data tidak lengkap & -74 \\
Jumlah Perusahaan yang dapat digunakan dalam penelitian & 65 \\
Tahun Penelitian & 4 \\
Total observasi & 260 \\
\hline
\end{tabular}

Sumber : Data Penelitian, 2021

Nilai perusahaan merupakan sebagai variabel dependen dalam penelitian ini. Proksi yang digunakan untuk mengukur nilai perusahaan adalah Tobin's $Q$ sebagaimana digunakan oleh Firmansyah \& Purnama (2020) yaitu sebagai berikut. $T O B I N^{\prime} S Q=\frac{E M V+D}{T A}$.

Keterangan :

EMV = Equity Market Value

$\mathrm{D} \quad=$ Total Kewajiban

TA $\quad=$ Total Aset

Variabel independen dalam penelitian ini adalah pengungkapan tanggung jawab sosial dan pengungkapan tata kelola perusahaan. Pengungkapan tanggung jawab sosial menggunakan sistem checklist dan pembobotan yang mengikuti standar GRI G4 yang sudah disesuaikan. Checklist yang digunakan memiliki 91 indikator yang terbagi menjadi tiga kategori, yaitu kategori ekonomi yang memiliki 9 indikator, kategori lingkungan yang memiliki 34 indikator, dan kategori sosial yang terdiri dari praktik ketenagakerjaan dan kenyamanan 
berjumlah 16 indikator, hak asasi manusia berjumlah 12 indikator, masyarakat berjumlah 11 indikator, dan tanggung jawab atas produk sebanyak 9 indikator. Sejalan dengan penelitian Lee (2015), penelitian ini menggunakan metode pengumpulan data content analysis untuk memberikan skor pada masing-masing item pengungkapan dalam laporan tahunan atau laporan keberlanjutan seperti yang tercantum di Tabel 2, sebagai berikut.

Tabel 2. Skala Indeks Pengungkapan Tanggung Jawab Sosial

\begin{tabular}{cl}
\hline Skala & \\
\hline 0 & Tidak melakukan pengungkapan \\
1 & Pengungkapan minimum atau disebutkan secara singkat \\
2 & Deskriptif: menyajikan dampak bagi perusahaan atau kebijakan yang jelas \\
3 & Kuantitatif: dampak bagi perusahaan secara jelas didefinisikan dalam istilah \\
& moneter atau kuantitas fisik. \\
4 & Truly extraordinary
\end{tabular}

Sumber: Data Penelitian, 2021

Skor yang diperoleh kemudian dijumlahkan untuk mendapatkan total skor masing-masing perusahaan. Pengungkapan tanggung jawab sosial dihitung dengan rumus berikut.

$$
\text { CSRI } I_{i t}=\frac{\sum X i t}{n}
$$

Keterangan :

CSRI $_{i t} \quad=$ Indeks tanggung jawab sosial perusahaan $\mathrm{i}$ pada tahun $\mathrm{t}$

$X_{i t} \quad=$ Nilai total pengungkapan tanggung jawab sosial perusahaan $\mathrm{i}$ pada tahun $\mathrm{t}$

$N \quad=$ Jumlah nilai maksimum pengungkapan tanggung jawab sosial

Variabel tata kelola dalam penelitian ini diukur dengan cara mengembangkan indeks yang terdiri dari lima dimensi pengukuran utama sesuai prinsip corporate governance yang dikeluarkan oleh OJK yaitu Surat Edaran Otoritas Jasa Keuangan Nomor 32 tahun 2015. Pengukuran tata kelola perusahaan pada penelitian ini merujuk pada Firmansyah et al. (2021) dan Putri et al. (2020) dengan modifikasi berdasarkan SE OJK tersebut. Indeks dibuat dengan cara menurunkan lima dimensi utama menjadi untuk membentuk indeks dengan skor 1 jika memenuhi dan 0 jika tidak memenuhi. Checklist tersebut kemudian dikalkulasi dan dirata-rata sehingga membentuk nilai yang berkisar antara 0-1. Dengan demikian, rumus tata kelola tersebut secara ringkas dapat dinyatakan sebagai berikut.

$\mathrm{CGov}_{\mathrm{i}, \mathrm{t}}=\frac{\text { skor stand tata kelola perusahaan terpenuhi }}{\text { total kriteria dalam checklist tata kelola perusahaan }}$.

Penelitian ini juga menggunakan tiga variabel kontrol yang terdiri dari leverage, profitabilitas dan ukuran perusahaan. Leverage merupakan rasio dari total utang dibagi total ekuitas sebagaimana digunakan oleh Munawar (2019) dan AlSlehat (2019). Selanjutnya, profitabilitas menunjukkan kemampuan perusahaan dalam menghasilkan laba bersih dengan menggunakan modal sendiri yang dapat diukur dengan return on equity (ROE) sebagaimana ditawarkan oleh Fauzi \& Nurmatias (2019). Sementara itu, ukuran perusahaan merupakan besar kecilnya suatu perusahaan yang dilihat dari besarnya aset yang dimiliki oleh perusahaan tersebut (Saemargani \& Mustikawati, 2015). Ukuran perusahaan pada penelitian menggunakan proksi yang digunakan Saksessia \& Firmansyah (2020) dan Astuti 
et al. (2018) yaitu logaritma natural dari aset perusahaan. Pengujian hipotesis dilakukan dengan analisis regresi berganda untuk data panel. Model penelitian utama dalam penelitian ini adalah sebagai berikut.

TOBIN'S Q ${ }_{i t}=a_{i t}+\beta_{1} C_{C R I}{ }_{i t}+\beta_{2} C_{i t}+\beta_{3} \mathrm{ROE}_{i t}+\beta_{4} \mathrm{LEV}_{\mathrm{it}}+\beta_{5} \mathrm{SIZE}_{\mathrm{it}}+\varepsilon_{\mathrm{it}}$

Keterangan:

TOBIN'S $_{\text {it }}=$ Firm Value perusahaan i untuk tahun $\mathrm{t}$

CSRI $_{i t}=$ CSR Disclosure Index perusahaan i untuk tahun $\mathrm{t}$

$\mathrm{CG}_{\mathrm{it}} \quad=$ Governance Disclosure Index perusahaan i untuk tahun $\mathrm{t}$

$\mathrm{ROE}_{\mathrm{it}} \quad=$ Return on Equity perusahaan i untuk tahun $\mathrm{t}$

$\mathrm{SIZE}_{\mathrm{it}} \quad=$ Ukuran Perusahaan perusahaan i untuk tahun $\mathrm{t}$

$\mathrm{LEV}_{\mathrm{it}} \quad=$ Leverage perusahaan $\mathrm{i}$ untuk tahun $\mathrm{t}$

\section{HASIL DAN PEMBAHASAN}

Tabel 3, menunjukkan statistik deskriptif dari variabel-variabel yang digunakan dalam penelitian ini.

Tabel 3. Statistik Deskriptif

\begin{tabular}{lcccccc}
\hline & CSRI & CGOV & ROE & LEV & SIZE & TOBIN'S Q \\
\hline Mean & 0,487 & 0,708 & 0,153 & 0,821 & 28,917 & 2,136 \\
Med. & 0,373 & 0,720 & 0,103 & 0,576 & 28,671 & 1,152 \\
Max. & 2,472 & 1,000 & 2,244 & 4,189 & 33,494 & 2,416 \\
Min. & 0,087 & 0,280 & 0,000 & 0,000 & 25,795 & 0,363 \\
Std. Dev. & 0,373 & 0,196 & 0,248 & 0,707 & 1,613 & 3,004 \\
Obs & 260 & 260 & 260 & 260 & 260 & 260 \\
\hline
\end{tabular}

Sumber: Data Penelitian, 2021

Berdasarkan pemilihan model melalui uji chow, uji hausman, dan uji lagrange multiplier, disimpulkan bahwa common effect model adalah model yang paling tepat digunakan dalam penelitian ini. Selanjutnya, uji asumsi klasik dilakukan dengan cara melakukan uji normalitas, uji multikolinearitas, dan uji heteroskedastisitas. Dalam uji normalitas, nilai probabilitas jarque-bera model penelitian lebih kecil dari nilai a $(0,05)$ sehingga data terdistribusi secara tidak normal. Akan tetapi, menurut Gujarati (2015) pelanggaran asumsi normalitas akan berdampak saat jumlah data sampel kecil. Batasan kecil tersebut adalah kurang dari 100 observasi. Dasar dari pernyataan tersebut adalah Central Limit Theorem yang menyatakan bahwa untuk data besar maka residual dianggap telah terdistribusi normal. Karena penelitian ini menggunakan 260 observasi, data dalam penelitian telah memenuhi asumsi untuk dinyatakan normal. Selanjutnya, untuk uji multikolinearitas, nilai seluruh matriks korelasi antara dua variabel bebas kurang dari 0,90 sehingga tidak terdapat masalah multikolinearitas pada model penelitian ini. Dalam uji heteroskedastisitas, berdasarkan hasil uji glesjer, terdapat beberapa variabel yang memiliki nilai probabilitas di bawah nilai a $(0,05)$, sehingga menunjukkan terdapat masalah heteroskedastisitas pada data panel. Terdapat treatment yang disediakan oleh ilmu ekonometrika untuk mengatasi masalah heteroskedastisitas (Reed \& Ye, 2011) dengan menggunakan estimator Feasible Generalized Least Square (FGLS) melalui aplikasi EViews 10, yaitu dengan memilih opsi cross-section weights. Oleh karena itu, dalam penelitian ini digunakan estimator cross-section weights pada aplikasi Eviews 10 untuk mengatasi masalah heteroskedastisitas. Adapun ringkasan hasil uji hipotesis adalah sebagai berikut. 
Tabel 4. Ringkasan Hasil Uji Hipotesis

\begin{tabular}{crrrr}
\hline Var & Coeff. & $t$-Stat. & Prob. & \\
\hline C & 17,718 & 10,861 & 0,000 & $* * *$ \\
CSRI & $-0,361$ & $-4,697$ & 0,000 & $* * *$ \\
CGOV & $-0,192$ & $-3,730$ & 0,000 & $* *$ \\
ROE & 0,747 & 2,588 & 0,010 & $* *$ \\
LEV & $-0,085$ & $-2,190$ & 0,029 & $* * *$ \\
SIZE & $-0,529$ & $-9,325$ & 0,000 & \\
$R^{2}$ & 0,981 & & & \\
Adj. $R^{2}$ & 0,973 & & & \\
F-stat. & 139,945 & & & \\
Prob(F-stat.) & 0,000 & & & \\
\hline
\end{tabular}

Sumber: Data Penelitian, 2021

Hipotesis pada penelitian ini perlu menentukan arah antar variabel sehingga prinsip yang digunakan pada model penelitian ini adalah one-tailed hypothesis. Berdasarkan pengujian hipotesis pertama, penelitian ini menemukan bahwa pengungkapan CSR berpengaruh negatif terhadap nilai perusahaan. Hasil pengujian ini tidak sesuai dengan hipotesis penelitian, sehingga hasil pengujian menunjukkan bahwa pengungkapan CSR tidak berpengaruh terhadap nilai perusahaan. Hasil penelitian ini tidak sejalan dengan Sejati \& Prastiwi (2015), Adhima \& Hariadi (2012) dan Tarigan \& Semuel (2014). Hasil pengujian ini bertentangan dengan resource-based view theory yang menyatakan bahwa perusahaan harus menggunakan sumber daya yang dimilikinya untuk mendapatkan keunggulan bersaing. Pasar tidak bereaksi terhadap informasi apapun tentang aktivitas kegiatan tanggung jawab sosial perusahaan dalam pengambilan keputusan terkait investasi. Perusahaan yang melaksanakan CSR dengan baik tidak dapat dianggap lebih transparan dan akuntabel baik dalam aktivitas lingkungan, sosial dan ekonomi. Aktivitas tanggung jawab sosial akan memaksa perusahaan untuk mengefisienkan penggunaan bahan baku dan meningkatkan pengelolaan limbah dan emisi lainnya untuk menjadikan kinerja perusahaan secara keseluruhan lebih efisien. Efisiensi ini mencerminkan kemampuan perusahaan dalam mengelola sumber daya secara optimal untuk menguntungkan perusahaan dan pemangku kepentingan, yang akan berdampak pada nilai perusahaan (Adhima \& Hariadi, 2012).

Idealnya, kegiatan lingkungan yang sesuai dianggap sebagai cara yang efektif untuk memaksimalkan penggunaan sumber daya perusahaan dan dianggap untuk mendapatkan keunggulan bersaing perusahaan. Sebagian besar perusahaan di Indonesia masih melakukan kegiatan CSR yang tidak berada dalam wilayah perspektif masyarakat tentang kegiatan CSR, yaitu kegiatan untuk meningkatkan keselamatan produk dan tempat kerja, kesejahteraan, dan keragaman karyawannya, dan lain sebagainya (Carroll \& Brown, 2018). Sebagian besar kegiatan CSR perusahaan ini adalah kegiatan sukarela dan filantropi, yang tidak diinginkan oleh publik (Carroll et al., 1995). Aktivitas perusahaan dalam tanggung jawab sosial yang diungkapkan oleh perusahaan kepada publik tidak mampu menciptakan keunggulan kompetitif yang dibutuhkan perusahaan untuk menarik perhatian pelaku pasar khususnya investor. Investor menganggap bahwa pengungkapan tanggung jawab sosial yang dilakukan perusahaan belum sepenuhnya sejalan dengan perspektif investor dalam pemenuhan kebutuhan 
investor. Oleh karena itu, informasi dalam pengungkapan tanggung jawab sosial tidak memicu reaksi pasar yang tercermin dari nilai perusahaan dianggap tidak berarti bagi investor (Sejati \& Prastiwi, 2015). Selain itu, walaupun perusahaan berusaha mengikuti trend sustainability saat ini yang dianggap dapat menjadi keunggulan kompetitif perusahaan, aktivitas tersebut ternyata tidak mampu untuk mendapatkan manfaat ekonomi dalam bentuk kinerja pasar.

Keterlibatan perusahaan dalam kegiatan CSR meningkatkan beban dan pengeluaran perusahaan yang mengarah pada penurunan laba perusahaan periode berjalan sehingga berdampak pada penurunan nilai perusahaan (Hafez, 2016). Fenomena tersebut dapat dipahami karena investor beranggapan bahwa tujuan utama perusahaan adalah memaksimalkan kekayaan pemegang saham (Arsoy et al., 2012), Cheung et al., 2013), dan (Nuryaman, 2013). Pengungkapan CSR yang dilakukan oleh perusahaan tidak dipandang sebagai sebuah strategi yang mampu memberikan nilai tambah bagi perusahaan dalam meraih pendapatan di masa sekarang dan mendatang. Oleh karena itu, meskipun perusahaan aktif dalam kegiatan CSR, investor tidak melihat hal tersebut sebagai sebuah keunggulan kompetitif sehingga tidak berpengaruh terhadap nilai perusahaan.

Aktivitas tanggung jawab sosial diharapkan dapat memenuhi kebutuhan pelaku pasar khususnya investor terkait dengan etika bisnis yang dilakukan oleh perusahaan saat ini. Dari sudut pandang perusahaan, aktivitas tanggung jawab sosial dapat digunakan sebagai strategi untuk menunjukkan bahwa aktivitasaktivitas tersebut erat kaitannya dengan keberlangsungan perusahaan di masa mendatang. Perusahaan ingin menunjukkan bahwa sumber daya yang digunakan oleh perusahaan mendukung adanya isu sustainability yang saat ini menjadi isu yang banyak diminati oleh berbagai kalangan. Dari sudut pandang investor, tindakan tersebut dianggap belum menjadi prioritas informasi dalam pengambilan keputusan investasi di pasar modal. Investor menganggap bahwa aktivitas CSR tidak terkait dengan strategi-strategi keunggulan bersaing yang dilakukan oleh perusahaan pada umumnya. Selain itu, investor mungkin menganggap bahwa aktivitas CSR di Indonesia belum saatnya untuk dijadikan sebagai informasi yang penting dalam menjelaskan strategi perusahaan dan keunggulan bersaing perusahaan.

Hasil pengujian hipotesis kedua menunjukkan bahwa tata kelola perusahaan berpengaruh negatif terhadap nilai perusahaan. Namun, hasil pengujian ini tidak sejalan dengan hipotesis penelitian, sehingga dapat disimpulkan bahwa tata kelola perusahaan tidak berpengaruh terhadap nilai perusahaan. Hasil penelitian ini tidak sejalan dengan penelitian Putu et al. (2014) yang menyatakan bahwa tata kelola perusahaan yang baik dapat meningkatkan nilai perusahaan. Hasil pengujian ini juga tidak sejalan dengan pandangan resource-base view theory, yang menyatakan bahwa pengungkapan tata kelola perusahaan dapat mendorong perusahaan untuk menerapkan tata kelola yang baik mengikuti praktik umum dan standar untuk meningkatkan reputasi perusahaan dan meningkatkan kepercayaan pemangku kepentingan dalam menginvestasikan dananya. Perusahaan tidak menggunakan isu tata kelola perusahaan sebagai strategi untuk meningkatkan nilai perusahaan. Seharusnya, dalam konteks RBV, perusahaan perlu menerapkan isu-isu yang menjadi 
perhatian para pemangku kepentingan, seperti tata kelola perusahaan yang ditetapkan oleh OJK Indonesia.

Salah satu faktornya adalah kurangnya standarisasi rekomendasi dalam pedoman yang dibuat oleh OJK Indonesia. Dalam Surat Edarannya, OJK menggunakan pendekatan "mematuhi" atau "menjelaskan" untuk menilai pelaksanaan pedoman tata kelola perusahaan yang direkomendasikan oleh OJK Indonesia. Pendekatan ini memberikan ruang bagi perusahaan untuk menafsirkan hasil pemahamannya masing-masing. Perbedaan interpretasi tersebut membuat pengungkapan tata kelola perusahaan tidak berfungsi sepenuhnya karena setiap perusahaan dapat mendefinisikan tata kelola menurut pandangan pribadinya. Akibatnya, pengungkapan tata kelola perusahaan hanya memenuhi persyaratan administrasi tetapi kurang memperhatikan kualitas (Saksessia \& Firmansyah, 2020), sehingga belum tercermin dalam kinerja atau aktivitasnya. Hal ini terlihat dari betapa mudahnya perusahaan menyatakan telah memenuhi rekomendasi namun tidak ada bukti yang mendukung klaimnya (rata-rata hanya memenuhi $70,89 \%$ dari rekomendasi).

Selain itu, investor di Indonesia belum memiliki perhatian terkait penerapan tata kelola perusahaan. Penerapan tata kelola perusahaan belum sesuai dengan harapan investor tentang praktik tata kelola perusahaan yang baik, sehingga informasi yang diungkapkan tidak dapat diandalkan untuk proses pengambilan keputusan oleh investor. Penelitian ini mendukung hasil penelitian yang dilakukan oleh Fatchan \& Trisnawati (2016) yang menyatakan bahwa investor tidak mempertimbangkan pengungkapan tata kelola perusahaan dalam keputusan mereka untuk melakukan investasi.

\section{SIMPULAN}

Informasi tanggung jawab sosial yang terdiri dari lingkungan, sosial, dan ekonomi bukan informasi yang dapat digunakan oleh investor dalam pengambilan keputusan. Informasi pengelolaan lingkungan yang diklaim oleh perusahaan dapat meningkatkan efisiensi perusahaan tidak dianggap sebagai informasi yang penting. Selain itu, investor beranggapan bahwa keterbukaan informasi sosial tidak dapat memberikan manfaat ekonomi yang signifikan bagi perusahaan, padahal manfaat ekonomis tersebut akan memberikan nilai tambah. Investor juga berasumsi bahwa informasi keuangan laporan tahunan sudah cukup untuk merepresentasikan informasi yang dibutuhkan investor dalam pengambilan keputusan sehingga pengungkapan ekonomi dalam Laporan Keberlanjutan hanyalah informasi tambahan yang tidak mempengaruhi nilai perusahaan. Selanjutnya, informasi pengungkapan tata kelola perusahaan dianggap memberikan ruang bagi perusahaan untuk menilai implementasi pedoman yang direkomendasikan OJK berdasarkan interpretasi masing-masing. Oleh karena itu, pengungkapan tata kelola perusahaan hanya sebatas memenuhi persyaratan administrasi tetapi belum tercermin dalam kinerja perusahaan.

Penelitian ini juga memiliki keterbatasan seperti penelitian lainnya. Pertama, populasi penelitian ini hanya terbatas pada perusahaan sektor manufaktur yang terdaftar di BEI periode 2016-2019, sehingga tidak dapat disimpulkan secara umum tentang populasi perusahaan di Indonesia dan juga tidak dapat menggambarkan perusahaan secara utuh. Kedua, perbedaan 
pemahaman konsep indikator yang berbeda dapat menyebabkan subjektivitas dalam menilai pengungkapan tanggung jawab sosial dan tata kelola perusahaan. Penelitian selanjutnya dapat menguji perusahaan dengan sektor yang berbeda dan dengan cakupan yang lebih luas. Penelitian selanjutnya juga dapat menggunakan pedoman GRI terbaru atau pedoman lain untuk melakukan penelitian tentang pengungkapan laporan keberlanjutan dan menggunakan pedoman lain untuk menilai pengungkapan tata kelola perusahaan, seperti standar OECD atau ASEAN scorecard index, yang lebih komprehensif.

Berdasarkan hasil pengujian dalam penelitian ini, Otoritas Jasa Keuangan selalu badan pengawas pasar modal di Indonesia perlu melakukan perbaikan dalam pengaturan tanggung jawab sosial dan tata kelola yang dilakukan oleh perusahaan. Selain itu, OJK perlu melakukan monitoring dalam implementasi aktivitas tanggung jawab sosial dan tata kelola perusahaan dalam menilai kualitas yang telah dilaksanakan perusahaan. Selanjutnya, OJK perlu melakukan sosialisasi atas implementasi tanggung jawab sosial kepada investor mengingat informasi aktivitas tanggung jawab sosial yang tercantum dalam laporan keberlanjutan mulai berlaku diwajibkan kepada perusahaan yang terdaftar di Bursa Efek Indonesia mulai tahun 2021.

\section{REFERENSI}

Adhima, M. F., \& Hariadi, B. (2012). Pengaruh Pengungkapan Sustainability Report terhadap Profitabilitas Perusahaan Studi Kasus pada Perusahaan Manufaktur yang Terdaftar dalam Bursa Efek Indonesia. Jurnal Ilmiah Mahasiswa FEB, 1(1).

Al-Slehat, Z. A. F. (2019). Impact of Financial Leverage, Size and Assets Structure on Firm Value: Evidence from Industrial Sector, Jordan. International Business Research, 13(1), 109. https://doi.org/10.5539/ibr.v13n1p109

Arsoy, A. P., Arabica, O., \& Ciftcioglu, A. (2012). Corporate Social Responsibility And Financial Performance Relationship: The Case Of Turkey. The Journal of Accounting and Finance, January(53), 159-176.

Astuti, F. Y., Wahyudi, S., \& Mawardi, W. (2018). Analysis Of Effect Of Firm Size, Institutional Ownership, Profitability, And Leverage On Firm Value With Corporate Social Responsibility (CSR) Disclosure As Intervening Variables (Study on Banking Companies Listed on BEI Period 2012-2016). Jurnal Bisnis Strategi, 27(2), 95-109. https:/ / doi.org/10.14710/jbs.27.2.95-109

Bahrun, M. F., Tifah, \& Firmansyah, A. (2020). Pengaruh Keputusan Pendanaan, Keputusan Investasi, Kebijakan Dividen, Dan Arus Kas Bebas Terhadap Nilai Perusahaan. Jurnal Ilmiah Akuntansi Kesatuan, 8(3), 263-276.

Barney, J. (1991). Firm Resources and Sustained Competitive Advantage. Journal of Management, 17(1), 99-120.

Branco, M. C., \& Rodrigues, L. L. (2006). Corporate Social Responsibility Perspectives. Journal of Business Ethics, 69, 111-132. https://doi.org/10.1007/s10551-006-9071-z

Carroll, A. B., \& Brown, J. A. (2018). Corporate Social Responsibility: A Review of Current Concepts, Research, and Issues. Corporate Social Responsibility, 39-69. https:// doi.org/10.1108/s2514-175920180000002002

Carroll, A., Sullivan, S., \& Markowitz, L. (1995). Understanding the Impact of 
Corporate Social Responsibility (CSR) in the Marketplace: A Reputation and Social Performance Assessment Study. Proceedings of the International Association for Business and Society, 6, 653-661. https://doi.org/10.5840/iabsproc1995658

Cheung, Y. L., Jiang, K., Mak, B. S. C., \& Tan, W. (2013). Corporate Social Performance, Firm Valuation, and Industrial Difference: Evidence from Hong Kong. Journal of Business Ethics, 114(4), 625-631. https://doi.org/10.1007/s10551-013-1708-0

Cormier, D., Ledoux, M. J., \& Magnan, M. (2011). The informational contribution of social and environmental disclosures for investors. Management Decision, 49(8), 1276-1304. https:/ / doi.org/10.1108/00251741111163124

Eccles, R. G., Newquist, S. C., \& Schatz, R. (2007). Reputations and Its Risks. Harvard Business Review, 2, 104-114.

Elkington, J. (1998). Accounting for the Triple Bottom Line. Measuring Business Excellence, 2(3), 18-22.

Fatchan, I. N., \& Trisnawati, R. (2016). Pengaruh Good Corporate Governance Pada Hubungan Antara Sustainability Report Dan Nilai Perusahaan (Studi Empiris Perusahaan Go Public di Indonesia Periode 2014-2015). Riset Akuntansi Dan Keuangan Indonesia, 1(1), 25-34. https://doi.org/10.23917/reaksi.v1i1.1954

Fauzi, A., \& Nurmatias, N. (2019). Pengaruh Profitabilitas Dan Leverage Terhadap Nilai Perusahaan Dengan Kebijakan Dividen Sebagai Variabel Intervening Pada Perusahaan Yang Terdaftar Di Bei Tahun 2013. Jurnal Ekonomi Dan Bisnis, 2(2), 177. https://doi.org/10.35590/jeb.v2i2.719

Firmansyah, A., Husna, M. C., \& Putri, M. A. (2021). Corporate Social Responsibility Disclosure, Corporate Governance Disclosures, and Firm Value In Indonesia Chemical, Plastic, and Packaging Sub-Sector Companies. Accounting Analysis Journal, 10(1), 9-17. https://doi.org/10.15294/aaj.v10i1.42102

Firmansyah, A., \& Purnama, E. B. D. (2020). Do Derivatives Instruments Ownership Decrease Firm Value in Indonesia? Riset Akuntansi Dan Keuangan Indonesia, 5(1), 1-9. https:// doi.org/10.23917/ reaksi.v5i1.9817

Firmansyah, A., Setiawan, T. A., \& Fathurahman, F. (2020). Nilai Perusahaan: Kebijakan Utang, Good Corporate Governance, Cash Holding. Jurnal Akuntansi Dan Bisnis, 20(2), 237. https:// doi.org/10.20961/jab.v20i2.568

Firmansyah, A., \& Triastie, G. A. (2020). The role of corporate governance in emerging market: Tax avoidance, corporate social responsibility disclosures, risk disclosures, and investment efficiency. Journal of Governance and Regulation, 9(3), 8-26. https:// doi.org/10.22495/jgrv9i3art1

Frensidy, B. (2019). The Effect of Hedging with Financial Derivatives on Firm Value at Indonesia Stock Exchange. Economics and Finance in Indonesia, 65, 2032.

Gaol, G. A. L., Firmansyah, A., \& Irawati, A. D. (2021). Intellectual Capital, Corporate Social Responsibility, And Firm Value in Indonesia's Banking Industries. Jurnal Riset Akuntansi Terpadu, 14(1), 76-87. https://doi.org/10.35448/jrat.v14i1.10229

Global Reporting Initiative. (2013). G4 Pedoman Pelaporan Keberlanjutan: 
Prinsip-prinsip Pelaporan dan Pengungkapan Standar. In The Netherlands: Global Reporting Initiative.

Goodell, J. W. (2020). COVID-19 and finance: Agendas for future research. Finance Research Letters, 35, 101512. https:/ / doi.org/10.1016/j.frl.2020.101512

Guidry, R. P., \& Patten, D. M. (2010). Market reactions to the first-time issuance of corporate sustainability reports: Evidence that quality matters. Sustainability Accounting, Management and Policy Journal, 1(1), 33-50. https:// doi.org/10.1108/20408021011059214

Gujarati, D. N. (2015). Dasar-Dasar Ekonometrika. Salemba Empat.

Gunawan, Y., \& Mayangsari, S. (2015). Pengaruh Sustainability Reporting Terhadap Nilai Perusahaan Dengan Investment Opportunity Set Sebagai Variabel Moderating. Jurnal Akuntansi Trisakti, 2(1), 1. https://doi.org/10.25105/jat.v2i1.4828

Hafez, H. (2016). Corporate social responsibility and firm value: an empirical study of an emerging economy. Journal of Governance and Regulation, 5(4), 40-53. https://doi.org/10.22495/jgr_v5_i4_p3

Handriani, E., \& Robiyanto, R. (2018). Corporate Finance and Firm Value in The Indonesian Manufacturing Companies. International Research Journal of Business Studies, 11(2), 113-127. https://doi.org/10.21632/irjbs.11.2.113-127

Handriani, \& Irianti, T. E. (2015). Investment Opportunity Set (IOS) Berbasis Pertumbuhan Perusahaan dan Kaitannya. Dengan Upaya Peningkatan Nilai Perusahaan. Jurnal Ekonomi Dan Bisnis, 18(1), 83-99.

Hart, S. L. (1995). A Natural-Resource-Based View of the Firm. The Academy OfManagement Review, 20(4), 986-1014.

Haryanto. (2020). Dampak Covid-19 terhadap Pergerakan Nilai Tukar Rupiah dan Indeks Harga Saham Gabungan (IHSG). Jurnal Perencanaan Pembangunan: The Indonesian Journal of Development Planning, 4(2), 151-165. https://doi.org/10.36574/jpp.v4i2.114

Hooghiemstra, R. (2000). Corporate Communication and Impression Management - New Perspectives Why Companies Engage in Corporate Social Reporting. Journal of Business Ethics, 27, 55-68. https://doi.org/https://doi.org/10.1023/A:1006400707757

Irawanti, G., Moeljadi, \& Indrawati, N. K. (2018). The Determinants of Hedging and Firm Value: An Empirical Study in Mining Companies Listed on Indonesia Stock Exchange. Management and Economics Journal (MEC-J), 2(1), 95-108. https:/ / doi.org/10.18860/ mec-j.v0i1.5017

Jo, H., \& Harjoto, M. A. (2011). Corporate Governance and Firm Value: The Impact of Corporate Social Responsibility. Journal of Business Ethics, 103(3), 351-383. https://doi.org/10.1007/s10551-011-0869-y

Klein, B., \& Leffler, K. B. (1981). The Role of Market Forces in Assuring Contractual Performance. Journal of Political Economy, 89(4), 615-641. https://doi.org/10.1086/260996

Latifah, S. W., \& Luhur, M. B. (2017). Pengaruh Pengungkapan Substainability Report Terhadap Nilai Perusahaan Dan Profitabilitas Sebagai Variabel Moderasi. Jurnal Akuntansi Dan Bisnis Universitas Muhammadiyah Malang, 17(1), 13-18. http://eprints.umm.ac.id/58102/7/Latifah Luhur Sustainability Report Profitability Firm Value.pdf 
Lee, K. H. (2015). Does Size Matter? Evaluating Corporate Environmental Disclosure in the Australian Mining and Metal Industry: A Combined Approach of Quantity and Quality Measurement. Business Strategy and the Environment, 26(2), 1-15.

Madhani, P. M. (2017). Diverse Roles of Corporate Board: A Review of Various Corporate Governance Theories. IUP Journal of Corporate Governance, 16(2), 728.

Mao, Y., He, J., Morrison, A. M., \& Andres Coca-Stefaniak, J. (2020). Effects of tourism CSR on employee psychological capital in the COVID-19 crisis: from the perspective of conservation of resources theory. Current Issues in Tourism, 1-19. https:// doi.org/10.1080/13683500.2020.1770706

Munawar, A. (2019). The Effect of Leverage, Dividend Policy, Effectiveness, Efficiency, and Firm Size on Firm Value in Plantation Companies Listed IDX. International Journal of Science and Research (IJSR), 8(10 October 2019), 9. https://doi.org/10.21275/ART20201693

Novianti, T., \& Firmansyah, A. (2020). The effect of tax risk, hedging, income smoothing, and cash flows volatility on firm value. Test Engineering and Management, 83(April), 9675-9686.

Nuryaman, A. R. (2013). The Effect of Corporate Social Responsibility Activites on Profitability and Stock Price: Studies on the Companies Listed on Indonesia Stock Exchange. Journal of Global Management, 6(1), 113-124.

Nuswandari, C. (2009). Pengungkapan Pelaporan Keuangan Dalam Perspektif Signalling Theory Oleh: Cahyani Nuswandari, SE.Ak Fakultas Ekonomi Universitas Stikubank. Kajian Akuntansi, 1(1), 48-57.

Pibri, H. (2021). The Influence of Corporate Governance on Firm Value and Bank Performance in The Pandemic Crisis in Indonesia. International Journal of Scientific and Research Publications (IJSRP), 11(3), 211-217. https:// doi.org/10.29322/ijsrp.11.03.2021.p11128

Porter, M. E. (1980). Competitive Strategy: Techniques for Analyzing Industries and Competitors. Free Press.

Putri, M. M., Firmansyah, A., \& Labadia, D. (2020). Corporate Social Responsibility Disclosure, Good Corporate Governance, Firm Value: Evidence from Indonesia's Food And Beverage Companies. The Accounting Journal of Binaniaga, 5(2), 113. https://doi.org/10.33062/ajb.v5i2.398

Putu, N. N. G. M., Moeljadi, Djumahir, \& Djazuli, A. (2014). Factors Affecting Firm Value: Theoretical Study on Public Manufacturing Firms in Indonesia. International Journal of Business and Management Invention, 3(2), 35-44.

Qiu, S. (Charles), Jiang, J., Liu, X., Chen, M. H., \& Yuan, X. (2021). Can corporate social responsibility protect firm value during the COVID-19 pandemic? International Journal of Hospitality Management, 93(June 2020), 102759. https://doi.org/10.1016/j.ijhm.2020.102759

Qiu, Y., Shaukat, A., \& Tharyan, R. (2016). Environmental and social disclosures: Link with corporate financial performance. British Accounting Review, 48(1), 102-116. https:// doi.org/10.1016/j.bar.2014.10.007

Raz, K. R., \& Amir, M. (2014). A Review of Interaction of Financial Leverage and Investment Opportunities on Dividend Policy. Researcher, 4.

Reed, W. R., \& Ye, H. (2011). Which panel data estimator should I use? Applied 
Economics, 43(8), 985-1000. https://doi.org/10.1080/00036840802600087

Riny. (2018). Analisis Faktor Yang Mempengaruhi Nilai Perusahaan Pada Perusahaan Perbankan Yang Terdaftar Di Bursa Efek Indonesia. Jurnal Wira Ekonomi Mikroskil, 8(2), 139-150. https://doi.org/10.31940/jbk.v14i3.1058

Russo, M. V., \& Fouts, P. A. (1997). A resource-based perspective on corporate environmental performance and profitability. Academy of Management Journal, 40(3), 534-559. https://doi.org/10.2307/257052

Saemargani, F., \& Mustikawati, I. (2015). Pengaruh Ukuran Perusahaan, Umur Perusahaan, Profitabilitas, Solvabilitas, Ukuran KAP, dan Opini Auditor terhadap Audit Delay. Jurnal Nominal, IV(2), 1-15.

Saksessia, D., \& Firmansyah, A. (2020). The Role Of Corporate Governance On Earnings Quality From Positive Accounting Theory Framework. International Journal of Scientific \& Technology Research, 9(1), 808-820.

Salman, I., Firmansyah, A., \& Widyaningrum, M. R. (2020). Peran Leverage Sebagai Pemoderasi: Revaluasi Aset Tetap, Kebijakan Dividen, Nilai Perusahaan. Jurnal Magister Akuntansi Trisakti, 7(2), 171. https://doi.org/10.25105/jmat.v7i2.7810

Sejati, B. P., \& Prastiwi, A. (2015). Pengaruh Pengungkapan Sustainability Report Terhadap Kinerja Dan Nilai Perusahaan. Diponegoro Journal of Accounting, $4(1), 1-12$.

Skinner, D. J., \& Soltes, E. (2009). What Do Dividends Tell Us About Earnings Quality. Review of Accounting Studies, 16(2), 1-28.

Sutrisno, S. (2020). Corporate Governance, Profitability, and Firm Value Study on the Indonesian Sharia Stock Index. Jurnal Ekonomi Dan Bisnis Islam (Journal of Islamic Economics and 292. https://doi.org/10.20473/jebis.v6i2.23231

Tarigan, J., \& Semuel, H. (2014). Pengungkapan Sustainability Report dan Kinerja Keuangan. Jurnal Akuntansi Dan Keuangan, 16(2), 88-101. https:// doi.org/10.9744/jak.16.2.88-101

Tyastari, T. T. D., Rosidi, \& Saraswati, E. (2017). Dividend Policy and Corporate Value (A Meta-Analysis). Jurnal Keuangan Dan Perbankan, 21(3), 344-355. https:// doi.org/DOI: 10.26905/jkdp.v21i3.1218

Wernerfelt, B. (1984). A Resource-Based View of the Firm. Strategic Management Journal, $5(2)$, 171-180. http://onlinelibrary.wiley.com/doi/10.1002/smj.4250050207/abstract

Whitelock, V. G. (2015). Environmental social governance management: A theoretical perspective for the role of disclosure in the supply chain. International Journal of Business Information Systems, 18(4), 390-405. https:// doi.org/10.1504/IJBIS.2015.068477

Zhang, D., Hu, M., \& Ji, Q. (2020). Financial markets under the global pandemic of COVID-19. Finance Research Letters, 36, 101528. https://doi.org/10.1016/j.frl.2020.101528 